УДК 371.134:004.383.8

Славецький Василь, ORCID iD 0000-0003-3463-7539 e-mail: slavetsk@ukr.net

Юрченко Валерій, ORCID iD $\underline{\text { 0000-0003-2238-1206 }}$

E-mail : valaleks@ukr.net

\title{
ДОСВІД ВИКОРИСТАННЯ ДИСТАНЦЙНОЇ ФОРМИ НАВЧАННЯ ДЛЯ ПРОФЕСІЙНОГО РОЗВИТКУ ДЕРЖАВНИХ СЛУЖБОВЦІВ
}

\author{
https://doi.org/10.32689/2618-0065-2021-2(8)-206-222
}

\begin{abstract}
Анотація. У статті розглянуто порядок організації підвищення кваліфікації керівного складу та фахівців, діяльність яких пов'язана 3 організацією i здійсненням заходів 3 питань цивільного захисту (далі - функціональне навчання) центральних органів виконавчої влади (далі - ЦОВВ) та здійснено аналіз організації функціонального навчання 3 посадовими особами керівного складу органів управління цивільного захисту за дистанційною формою навчання. Детально проаналізований досвід щодо використання дистанційної форми навчання для підвищення кваліфікації 3 питань цивільного захисту із зазначеною категорією слухачів, визначені переваги та недоліки дистанційної форми навчання. Здійснений аналіз теоретичних та практичних аспектів реалізації дистанційної форми навчання в роботах вітчизняних учених. Розглянуто перелік компетентностей посадових осіб керівного складу органів управління цивільного захисту центральних органів виконавчої влади, які рекомендовано набувати за допомогою аудиторного навчання, компетентностей, які доцільно розвивати за допомогою самонавчання 3 використанням електронних ресурсів, а також компетентностей, які необхідно набувати за допомогою навчання на робочому місці. Проаналізовано практичний досвід кафедри організації заходів цивільного захисту щодо організації підвищення кваліфікації керівного складу та фахівців, діяльність яких пов'язана 3 організацією i здійсненням заходів 3 питань цивільного захисту ЦОВВ 3 виростанням дистанційної форми навчання в умовах запровадження на території держави карантину у зв'язку з вірусною хворобою COVID-19. Визначено, що основні зусилля науково-педагогічних працівників на кафедрі спрямовані на організацію інтерактивного навчання, на відпрацювання та реалізацію компонентів та методів інтерактивних технологій 3 використанням комп'ютерної підтримки, якісну розробку методичних матеріалів для проведення теоретичних i, особливо, практичних занять в режимі ONLINE. За результатами дослідження установлено значну ефективність інтерактивного навчання щодо засвоєння слухачами навчального матеріалу. Авторами статті запропоновано ефективну форму організації навчального
\end{abstract}


процесу з функціонального навчання з використанням електронних ресурсів в умовах запровадження карантину у зв'язку з вірусною хворобою COVID19, визначено напрями подальших досліджень за темою статті.

Ключові слова: державне управління, підвищення кваліфікації (професійний розвиток), дистанційна форма навчання, цивільний захист, державний службовець, функціональне навчання, органи державного управління.

Постановка проблеми. Ефективність публічного управління залежить від сучасного рівня професійної компетентності державних службовців. Дотримання цього рівня вимагає від них постійного професійного розвитку. Згідно чинного законадавства (Закону України «Про державну службу») професійний розвиток це безперервний, свідомий, цілеспрямований процес особистісного та професійного зростання, що базується на інтеграції знань, умінь і компетентностей.

«Реформа професійного навчання, як важлива складова реформи державного управління, зорієнтована на потреби публічного службовця у професійному розвитку та сприяє впровадженню принципів належного врядування» - зазначає голова НАДС Н. Алюшина [1]

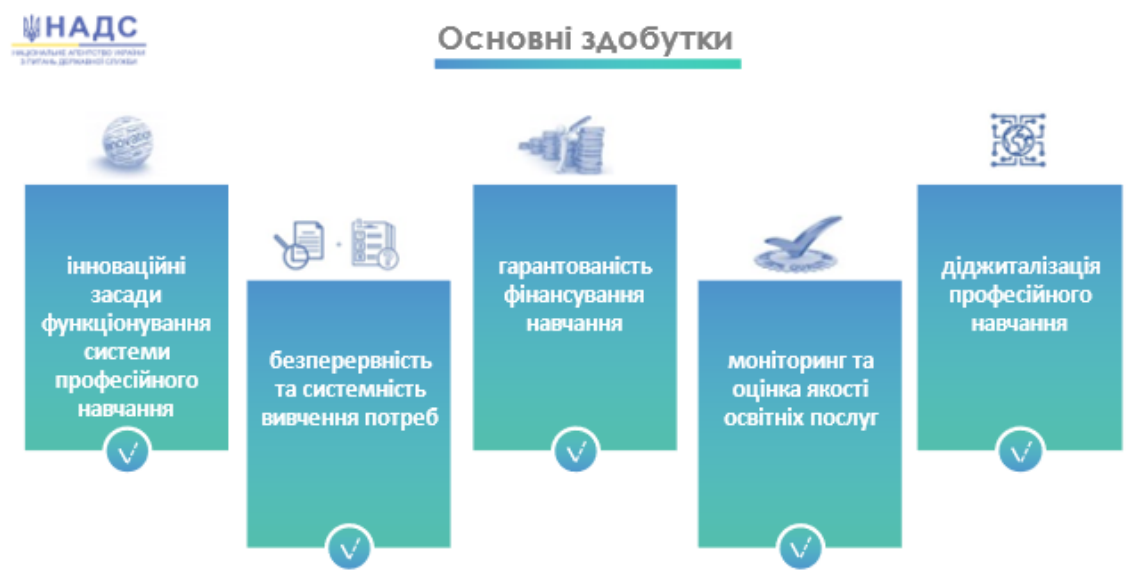

Рисунок 1 - Засади професійної розвитку державних службовців [1]

Належне врядування у сфері цивільного захисту залежить від рівня функціональної компететності у сфері цивільного 


\section{Науковий вісник : державне управління № 2(8) 2021}

захисту деяких категорій державних службовців, на яких покладається виконання додаткових завдань в цій сфері. Цільове підвищення їх кваліфікації, як одна із форм професійного розвитку державних службовців проводиться відповідно до Порядку навчання керівного складу та фахівців, діяльність яких пов'язана з організацією і здійсненням заходів 3 питань цивільного захисту [4]. Навчання керівного складу i фахівців для потреб центральних органів виконавчої влади (далі - ЦОВВ) здійснюється в Інституті державного управління та наукових досліджень з цивільного захисту (далі - ІДУНДЦЗ).

У сучасній освіті організація навчального процесу здійснюється 3 використанням новітніх інформаційних технологій, відповідних навчальних платформ, безпосередньо на робочому місці, зокрема із використанням дистанційної форми навчання. Невипадково Н. Алюшина наголошує на вимозі часу - діджиталізації підвищення кваліфікації (професійного навчання) державних службовців (рис. 1). На основі застосування сучасних інформаційно-комунікаційних технологій НАДС створено Портал управління знаннями зокрема і для : організації електронної взаємодії суб'єктів Порталу 3 метою забезпечення професійного розвитку державних службовців, обміну практиками та досвідом [2].

Нагальним завданням для органів управління галузевою освітою на шляху забезпечення «цивільної безпеки для суспільства», Є. Литвиновський пропонує визначити завдання створення інформаційної електронної платформи обміну науковою, навчально-методичною інформацією, координації методичного забезпечення освітньої (наукової) діяльності різних суб'єктів освітніх (наукових) організацій, що займаються питаннями цивільної безпеки [3, с. 27]. Науковець пропонує об єднати надбання у сфері застосування інформаційнокомунікаційних технологій організації навчання різних суб єктів галузевої системи освіти і науки на єдиній платформі управління галузевими знаннями.

Таким надбанням ІДУНДЦЗ стало організація функціонування дистанційної форми навчання для різних категорій слухачів-державних службовців.

Питання організації підвищення кваліфікації з посадовими 
особами керівного складу органів управління цивільного захисту ЦОВВ за дистанційною формою навчання в режимі ONLINE особливо постало за умови впровадження карантину у зв'язку з вірусною хворобою COVID-19 [5-7].

Аналізу проблем i здобутків організації професійного розвитку державних службовців (на прикладі керівників та фахівців, діяльність яких пов язана діяльність яких пов'язана 3 організацією і здійсненням заходів з питань цивільного захисту) і присвячена дана стаття.

Аналіз останніх досліджень і публікацій. Теоретичні та практичні аспекти реалізації дистанційної форми навчання розглядаються в роботах багатьох вчених (Л. Штихно, Л. Ліщинської, О. Романовського, О. Квасника В. Мороза, Н. Підбуцької, С. Резніка А. Черкашина, В. Шаповалової та ін.)

Л. Штихно зазначає переваги використання дистанційної освіти в навчальному процесі: наближеність освітніх послуг до місця проживання та роботи особи (умовно, за рахунок використання інформаційних мереж для створення навчального контенту i використання різноманітних інструментів на електронній освітній платформі Moodle), забезпечення умов до самоосвіти та професійного розвитку протягом усього життя, індивідуалізація, гнучкий графік навчання тощо [9].

Л. Ліщинська, розглядаючи дистанційне навчання як сучасну освітню технологію вказує на преференції для слухачів: можливість навчатися у будь-який час, можливість навчатися в будь-якому місці, навчання без відриву від основної діяльності, можливість навчатися у своєму темпі, доступність навчальних матеріалів, мобільність, навчання в спокійній обстановці, індивідуальний підхід, дистанційна освіта дешевша, зручність для викладача [10];

Колективом вчених за керівництвом О. Романовського здійснено аналіз тенденцій розвитку масових відкритих онлайнкурсів, огляд змісту нормативно-правового забезпечення щодо функціонування дистанційної освіти та авторську класифікацію основних переваг та недоліків впровадження освіти на відстані. Визначено, що основними недоліками дистанційного навчання $\epsilon$ необхідність сильної мотивації, нестача практичних вмінь та навиків, дистанційна освіта не підходить для розвитку 


\section{Науковий вісник : державне управління № 2(8) 2021}

комунікабельності, проблема ідентифікації слухача, посилює соціальну ізольованість [11].

М. Андрос, К. Черненко розглядає питання організації дистанційного навчання в надзвичайних освітніх умовах та в умовах COVID-19 [12, 13].

Г. Гайович, Н. Романюк визначено переваги хмарних технологій та динамічного навчального середовища Moodle для організації навчання фахівців сфери цивільного захисту [14].

У статті В. Юрченка розглянуто форми здобуття освіти для професійної підготовки державних службовців та посадових осіб місцевого самоврядування (далі - державні службовці), зокрема за інституційною (очною, дистанційною, мережевою, змішаною, дуальною та на робочому місці) формою навчання [15].

Проте питання організації функціонального навчання 3 питань цивільного захисту із посадовими особами керівного складу органів управління цивільного захисту ЦОВВ, зокрема за дистанційною формою навчання в умовах впровадження карантину залишається недостатньо дослідженим.

Мета статті. Аналіз досвіду та узагальнення наявних підходів щодо організації професійного розвитку державних службовців (на прикладі навчання керівного складу та фахівців, діяльність яких пов'язана з організацією і здійсненням заходів 3 питань цивільного захисту ЦОВВ в ІДУНДЦЗ, зокрема - за дистанційною формою навчання).

Методи дослідження. Аналіз попередніх досліджень 3 метою визначення найбільш ефективної форми підвищення кваліфікації керівників цивільного захисту ЦОВВ, інтернетопитування слухачів за проблематикою дослідження; спостереження за організації функціонування системи дистанційної освіти на кафедрі цивільного захисту.

Виклад основного матеріалу. Вдосконалити організацію навчання (професійного розвитку) керівного складу та фахівців, діяльність яких пов'язана 3 організацією i здійсненням заходів 3 питань цивільного захисту ЦОВВ за дистанційною формою навчання можливо шляхом визначення особливостей основних складових педагогічної системи 
функціонального навчання у сфері цивільного захисту (категорії слухачів, цілей їх навчання, змісту навчання, процесу навчання, організаційні форми і засоби навчання).

До категорій слухачів, які навчаються в ІДУНДЦЗ за навчальною програмою функціональною навчання відносяться особи керівного складу органів управління цивільного захисту центральних органів виконавчої влади.

Особливістю діяльності посадових осіб ЦОВВ $є$ постійна їх зайнятість, безперервність робочого процесу, висока відповідальність за прийняті управлінські рішення тощо.

Метою навчання $є$ набуття та систематичне оновлення посадовою особою спеціальних знань, умінь і навичок з питань цивільного захисту без вдосконалення раніше набутих нею компетентностей у межах професійної діяльності або галузі знань[16].

Змістом навчання для зазначеної категорії слухачів $\epsilon$ навчальна програма підвищення кваліфікації (функціонального навчання), яка передбачає структуру, зміст і обсяг навчальної інформації, засвоєння якої забезпечує слухачу можливість підвищення кваліфікації з питань цивільного захисту.

Процес навчання здійснюється відповідно до вимог нормативного документу [4].

У цілому, на основі аналізу змісту всіх компетентностей посадових осіб ЦОВВ з питань цивільного захисту, проведеного дослідження методом бесіди зі слухачами, їх анкетування, вивчення випускних робіт слухачів визначено, що в умовах впровадження в державі карантину близько $60 \%$ теоретичного навчального матеріалу слухачам необхідно засвоювати в години самостійної роботи 3 використанням електронних ресурсів за всіма темами занять відповідно до програми функціонального навчання. 3 цією метою в ІДУНДЦЗ використовується платформа Moodle, зміст якої наповнений навчальними матеріалами кафедрою організації заходів цивільного захисту (далі - кафедра).

Відповідно до вимог основних положень нормативноправових документів щодо організації дистанційної форми навчання у закладах вищої освіти, відомо з [18], на кафедрі організації заходів цивільного захисту ІДУНДЦЗ організовано 


\section{Науковий вісник : державне управління № 2(8) 2021}

підвищення кваліфікації керівного складу та фахівців, діяльність яких пов'язана з організацією і здійсненням заходів 3 питань цивільного захисту ЦОВВ.

Основні зусилля науково-педагогічних працівників (далі викладачі) на кафедрі спрямовані на організацію інтерактивного навчання.

Як відомо, основою інтерактивного навчання $\epsilon$ майстерність взаємодії в навчанні всіх учасників навчального процесу, а компонентами інтерактивних технологій $\epsilon$ інтерактивні методи навчання 3 використанням технічних засобів (комп'ютерна підтримка та ін.) і методичних матеріалів.

Установлено, що інтерактивне навчання значно збільшило процент засвоєння навчального матеріалу слухачами, оскільки впливає не лише на свідомість слухача, а й на відпрацювання ним управлінського рішення під час проведення практичного заняття методом ділової гри. Якщо на лекційних заняттях процент засвоєння навчального матеріалу складав близько 15$30 \%$, то на практичних - до 80-90\%.

Використовуючи ділові та ситуаційні ігри, кейс-стаді, головним чином, для формування практичних умінь та навичок, розв'язання завдань управління ліквідацією наслідків надзвичайної ситуації, ми вирішуємо головне завдання навчати керівників цивільного захисту ЦОВВ приймати ефективне управлінське рішення під час виникнення надзвичайної ситуації.

Досвід показує, що використання на кафедрі під час організації освітнього процесу активних форм навчання, а саме: діалогу, дискусій, ділових ігор, моделювання ситуацій сприяють формуванню поважного відношення до іншої думки, розуміння важливості існування різних підходів, сприйняттю різнодумства всередині навчальної групи як позитивного чинника.

Серед найбільш вживаних на кафедрі інтерактивних методів навчання є наступні:

метод мозкової атаки - це метод розв'язання невідкладних складних завдань за короткий час. Наприклад прийняття управлінських рішень під час проведення групової вправи за темою: «Практичне відпрацювання варіанту управлінського 
рішення при загрозі та виникненні надзвичайної ситуації»;

круглий стіл - метод проведення заняття із слухачами обговорення практичного досвіду, досягнень і помилок, які були допущені під час прийняття ними своїх рішень;

тематична дискусія - активний метод проведення занять, покликаний мобілізувати практичні й теоретичні знання, погляди слухачів на проблему, що розглядається;

ситуаційний аналіз проблеми, це коли слухачі самостійно аналізують ситуацію, діагностують проблему й надають свої ідеї й рішення в дискусії з іншими слухачами.

В той самий час, посадові особи ЦОВВ мають статус державних службовців і на них розповсюджуються вимоги, відомо [18], зокрема щодо основних принципів, на яких базується їх навчання, а саме:

обов'язковості та безперервності навчання протягом проходження державної служби;

цілеспрямованості, прогностичності та випереджувального характеру;

інноваційності та практичної спрямованості;

індивідуалізації та диференціації підходів до навчання;

відкритості та академічної доброчесності;

наближеності освітніх послуг до місця проживання та проходження служби особи;

гарантованості фінансування професійного навчання.

Подальший аналіз основних принципів навчання державних службовців показав, що запровадження дистанційного навчання для керівників ЦОВВ 3 питань цивільного захисту $\epsilon$ ефективною формою організації підвищення кваліфікації, особливо в період запровадження в державі жорсткого карантину у зв'язку з вірусною хворобою COVID-19.

Дистанційне навчання - це сукупність сучасних технологій, що забезпечують подання інформації в інтерактивному режимі за допомогою використання ІКТ від тих, хто навчає, до тих, хто навчається (студентів чи слухачів). Основними принципами дистанційного навчання $\epsilon$ інтерактивна взаємодія у процесі роботи, надання студентам чи слухачам можливості самостійного освоєння навчального матеріалу, а також консультаційний супровід у процесі навчання. Дає змогу 


\section{Науковий вісник : державне управління № 2(8) 2021}

навчатися на відстані за відсутності викладача. Основну роль у здійсненні дистанційного навчання відіграють сучасні інформаційні технології $[8,18]$.

Вагомими причинами впровадження дистанційного навчання для зазначеної категорії слухачів $\epsilon$, відомо [9-11] :

можливість навчатися у будь-який час, тобто будувати для себе індивідуальний графік навчання;

можливість навчатися в будь-якому місці, тобто вчитися, не виходячи з офісу, відсутність необхідності щодня відвідувати навчальний заклад;

навчання без відриву від основної діяльності. Для категорії державних службовців це дуже важливо, тобто підвищувати кваліфікацію на основному місці роботи;

можливість навчатися у своєму темпі, тобто пристосовуватись до умов, які склалися;

доступність навчальних матеріалів, тобто всі навчальні матеріали отримувати електронною поштою;

мобільність, тобто проконсультуватися 3 викладачем за допомогою електронної пошти ефективніше та швидше;

навчання в спокійній обстановці (у своєму робочому кабінеті);

індивідуальний підхід (може оперативно отримати у викладача відповіді на виникаючі питання);

зручність для викладача, який може працювати, навіть перебуваючи у відрядженні чи на конференції за кордоном або у домашніх умовах під час запровадження карантину (за умови наявності персонального комп'ютера та доступу до мережі інтернета).

Як бачимо, мета, завдання та вагомі переваги дистанційного навчання повністю сприяють реалізації основних принципів підвищення кваліфікації посадових осіб ЦОВВ 3 питань цивільного захисту.

Нові інформаційні технології в навчальному процесі - це не тільки використання мультимедійних засобів інтернеттехнологій на лекціях, семінарах, практичних заняттях, а й створення такого інформаційно-освітнього середовища, яке забезпечує задоволення різноманітних інформаційних потреб для всіх учасників навчального процес. 
Розроблені на кафедрі навчально-методичні матеріали, а саме: методичні вказівки щодо виконання самостійної роботи слухачами за темами: «Методика проведення розрахунку сил та засобів для організації робіт з ліквідації наслідків надзвичайних ситуацій», «Практичне відпрацювання управлінського рішення при загрозі та виникненні надзвичайної ситуації внаслідок виливу НХР», «Практичне відпрацювання управлінського рішення при загрозі та виникненні надзвичайної ситуації внаслідок викиду радіоактивних речовин», «Практичне відпрацювання управлінського рішення при загрозі та виникненні надзвичайної ситуації в разі землетрусу», «Практичне відпрацювання управлінського рішення при загрозі та виникненні надзвичайної ситуації в разі виникнення пожежі» передбачають активну роботу слухачів i викладачів в інтерактивному режимі. Доступ слухачів до електронних аналогів навчальних курсів здійснюється через платформу Moodle ІДУНДЦЗ за допомогою індивідуального пароля. Викладачі при такій організації роботи не тільки подають новий навчальний матеріал, а й відстежують, що дуже важливо, скільки часу кожен слухач вивчав конкретну навчальну тему, яких результатів за підсумками тестування досяг.

Разом із тим, аналіз практичного досвіду використання дистанційної форми навчання для підвищення кваліфікації посадових осіб ЦОВВ з питань цивільного захисту виявив деякі аспекти щодо необхідності подальшого удосконалення організації навчання зазначеної категорії слухачів за дистанційною формою навчання.

Слід зазначити, що успішно провести групову вправу за темою: «Практичне відпрацювання варіанту управлінського рішення при загрозі та виникненні надзвичайної ситуації» в онлайн-режимі 3 використанням інформаційних технологій вкрай складно.

Слід зазначити, що мова йде про проведення абсолютно всіх занять відповідно до навчальної програми за дистанційною формою навчання в режимі ONLINE. Ця обставина, як підтверджує практика, вимагає від викладачів особливо ретельної розробки навчально-методичних матеріалів для проведення практичних занять методом ділової гри в режимі 


\section{Науковий вісник : державне управління № 2(8) 2021}

форуму (конференції), коли адміністратором є викладач, який відповідно до розробленого плану сценарію проведення ділової гри (кейсу), почергово надає слово слухачам для їх заслуховування.

Дистанційна форма навчання вимагає від викладача наступне:

за короткий час опанувати електронними засобами в роботі; оволодіти технологіями дистанційного навчання;

уміти планувати графік своєї роботи, визначати базові інструменти та платформ, виробити чіткий алгоритм дій, скласти графік онлайн-зустрічей зі слухачами, створювати групу або спільноту зі слухачами в зручному месенджері та повідомляти через електронне посилання про дату і час занять;

навчитись організовувати та проводити відеоконференції, форуми, спілкуватись у Чаті зі слухачами в мережі в режимі реального часу онлайн тощо.

Платформа Moodle (https://moodle.org/) — безкоштовна відкрита система управління дистанційним навчанням, дозволяє використовувати широкий набір інструментів для освітньої взаємодії викладача, слухачів та адмі-ністрації закладу вищої освіти. Зокрема, надає можливість подавати навчальний матеріал у різних форматах (текст, презентація, відеоматеріал, веб-сторінка; заняття як сукупність веб-сторінок з можливим проміжним виконанням тестових завдань); здійснювати тестування та опитування слухачів 3 використанням питань закритого (множинний вибір правильної відповіді та зіставлення) і відкритого типів; слухачі можуть виконувати завдання з можливістю пересилати відповідні файли. Крім того, система має широкий спектр інструментів моніторингу навчальної діяльності слухачів, на-приклад: щодо загального часу роботи з конкретним навчальним предметом, відповідними темами або складниками навчального матеріалу, виконання тестових завдань тощо. Moodle має у своєму інструментарії: форми здавання завдань; дискусійні форуми; завантаження файлів; журнал оцінювання; обмін повідомленнями; календар подій; новини та анонси; онлайн-тестування; Вікі-ресурси тощо. До недоліків відноситься неможливість установити недоброчесні дії окремих слухачів щодо виконання тестових 
завдань та реального часу знаходження безпосередньо у комп'ютера під вивчення навчального матеріалу.

Винятковою особливістю в цій ситуації (повної ізоляції) $\epsilon$ здатність викладача виконувати свої функції в режимі ONLINE не виходячи зі своєї квартири за умови наявності всіх інструментів для проведення занять.

Щодо ризиків дистанційного навчання - це відсутність живого спілкування, яке може привести до деградації особистості, наслідками цього можуть бути роздратованість, замкнутість, хвороби, поганий настрій тощо.

Висновки та напрями подальших досліджень. Таким чином, за результатами проведеного аналізу досвіду використання дистанційної форми навчання для підвищення кваліфікації посадових осіб керівного складу органів управління цивільного захисту в умовах запровадження карантину виявлено наступне:

переваги дистанційної форми навчання надають змогу посадовим особам ЦОВВ близько $60 \%$ теоретичного навчального матеріалу, розробленого кафедрою, опанувати шляхом самовивчення з використанням електронних ресурсів 3 подальшою можливістю перевірки рівня отриманих знань;

3 метою більш якісного отримання знань слухачами 3 питань цивільного захисту доцільно під час організації підвищення кваліфікації за дистанційною формою навчання проводити групові вправи методом ділової (ролевої) гри 3 відпрацюванням дій органів управління цивільного захисту в разі загрози та виникнення надзвичайних ситуацій різних за походженням та рівнями.

В умовах карантину як слухачів, так і викладачів необхідно стимулювати до більш активного відвідування освітніх порталів 3 метою ефективного використання інформаційних ресурсів навчального, навчально-методичного, довідникового призначення для більш якісної підготовки та проведення занять в режимі ONLINE.

Напрямом подальшого дослідження $є$ визначення теоретико-методологічних, науково-практичних, технологічних умов розвитку функціонування інформаційно-освітнього середовища в ІДУНДЦЗ як кластеру професійного розвитку 


\section{Науковий вісник : державне управління № 2(8) 2021}

державних службовців та цілісної системи, яка забезпечує педагогічну взаємодію учасників освітнього процесу, інших стейкхолдерів, зацікавлених в створенні належного врядування у сфері цивільного захисту.

\section{Список використаних джерел}

1. Алюшина Н. Реформа професійного навчання є однією із складових реформи державного управління // Портал управління знаннями / НАДС. URL : https://cutt.ly/knkxsQE (дата звернення 12.05.2021).

2. Портал управління знаннями / НАДС. URL : https://pdp.nacs.gov.ua/pages/about (дата звернення 12.05.2021).

3. Литвиновський Є.Ю. На шляху до створення альянсу компетентностей 3 цивільної безпеки та його електронного прототипу. Nauka i obrazovanje u svetskom informacionom prostoru. Zbornik naučnih radova. Српска развојна асоцијација, Бачки Петровац. 2021. S. 24-27.

4. Про затвердження Порядку проведення навчання керівного складу та фахівців, діяльність яких пов'язана з організацією і здійсненням заходів 3 питань цивільного захисту: постанова Кабінету Міністрів України від 23 жовтня 2013 р. № 819. Офіційний вісник Украӥни.2013. № 89. С. 34.

5. Про запобігання поширенню на території України гострої респіраторної хвороби COVID-19, спричиненої коронавірусом SARS-CoV-2019 : постанова Кабінету Міністрів України від 11 березня 2020 р. № 211. Офіційний вісник Украӥни. 2020. № 23, С. 296.

6. Про встановлення карантину та запровадження посилених протиепідемічних заходів на території зі значним поширенням гострої респіраторної хвороби COVID-19, спричиненої коронавірусом SARS-CoV2: постанова Кабінету Міністрів України від 22 липня 2020 р. № 641. Офіційний вісник Украӥни. 2020. № 63. С. 22.

7. Про встановлення карантину з метою запобігання поширенню на території України гострої респіраторної хвороби COVID-19, спричиненої коронавірусом SARS-CoV-2: постанова Кабінету Міністрів України від 9 грудня 2020 р. № 1236. Офіційний вісник Украӥни. 2020. № 43. С. 118.

8. Про затвердження Положення про дистанційне навчання: наказ М-ва освіти і науки України від 25 квітня 2013 р. № 466. Офіційний вісник Украӥни. 2013. № 36, С. 202.

9. Штихно Л. В. Дистанційне навчання як перспективний напрям розвитку сучасної освіти. Молодий вчений. 2016. № 6. С. 489-493.

10. Ліщинська Л. Б. Дистанційне навчання як сучасна освітня технологія: матеріали міжвузівського вебінару, 31берез. 2017 р. Вінниця: ВТЕІ KHTEУ, 2017. $102 \mathrm{c}$.

11. Фактори розвитку та напрями вдосконалення дистанційної форми навчання в системі вищої освіти України. Інформаційні технології $i$ засоби навчання / Романовський О. Г. та ін. 2019. № 6, т. 74. С. 20-42.

12. Андрос М. Є. Питання організації дистанційного навчання в надзвичайних освітніх умовах. Дистанційна освіта в Украӥні: інноваџійні, нормативно-правові, педагогічні аспекти: зб. матеріалів доп. учасн. I Всеукр. наук.-практ. конф., 16 червн. 2020 р. Київ: НАУ, 2020. С. $8-10$. 


\section{Науковий вісник : державне управління № 2(8) 2021}

13. Черненко К. В. Дистанційне навчання у вищій школі в умовах COVID19. Дистанційна освіта в Украӥні: інновачійні, нормативно-правові, педагогічні аспекти: зб. матеріалів доп. учасн. I Всеукр. наук.-практ. конф., 16 червн. 2020 р. Київ: НАУ, 2020. С. 138-140.

14. Гайович Г. В., Романюк Н. М. Використання систем дистанційного доступу до інформації в навчанні фахівців сфери цивільного захисту: практичний досвід. Дистанизійна освіта в Украӥні: інноваційні, нормативно-правові, педагогічні аспекти: зб. матеріалів доп. учасн. I Всеукр. наук.-практ. конф., 16 червн. 2020 р. Київ: НАУ, 2020. С. 26-29.

15. Юрченко В. О. Використання інноваційних форм здобуття освіти та методів навчання для підготовки державних службовців і посадових осіб місцевого самоврядування. Науковий вісник: державне управління. Інститут державного управління та наукових досліджень з иивільного захисту. Київ: 2021. №1. С. 303-317. URL : https://doi.org/10.32689/26180065-2021-1(7)-303-317.

16. Про деякі питання організації навчального процесу з функціонального навчання: наказ МВС України від 23 квітня 2019 р. № 302. Офічіийний вісник України. 2019. № 45. С. 136.

17. Про затвердження Вимог до вищих навчальних закладів та закладів післядипломної освіти, наукових, освітньо-наукових установ, що надають освітні послуги за дистанційною формою навчання 3 підготовки та підвищення кваліфікації фахівців за акредитованими напрямами i спеціальностями: наказ М-ва освіти і науки України від 30 жовтня 2013 р. № 1518.Офіційний вісник Украӥни. 2013. № 88, С. 156.

18. Про затвердження Положення про систему підготовки, спеціалізації та підвищення кваліфікації державних службовців i посадових осіб місцевого самоврядування: постанова Кабінету Міністрів України від 06 лютого 2019 р. № 106. Офіиійний вісник України.2019. № 19. С. 43-52.

\section{References}

1. Aliushyna N. Reforma profesiinoho navchannia ye odniieiu iz skladovykh reformy derzhavnoho upravlinnia [Vocational training reform is one of the components of public administration reform] // Portal upravlinnia znanniamy / NADS. Retrieved from : https://cutt.ly/NbMP5ME.

2. Portal upravlinnia znanniamy [Knowledge management portal] / NADS. Retrieved from https://pdp.nacs.gov.ua/pages/about (data zvernennia 12.05.2021).

3. Lytvynovskyi Ye.Iu. Na shliakhu do stvorennia aliansu kompetentnostei z tsyvilnoi bezpeky ta yoho elektronnoho prototypu [On the way to creating an alliance of civil security competencies and its electronic prototype]. Nauka i obrazovanje u svetskom informacionom prostoru. Zbornik naučnih radova. Srpska razvojna asotsyjatsyja, Bachky Petrovats. 2021. $140 \mathrm{~s}$.

4. Postanova Kabinetu Ministriv Ukrainy Pro zatverdzhennia Poriadku pro vedennia navchannia kerivnoho skladu ta fakhivtsiv, diialnist iakykh poviazana $\mathrm{z}$ orhanizatsiiu i zdiisnenniam zakhodiv z pytan zyvilnoho zakhystu 23 zhovtnia 2013 roku № 819 [On approval of the Procedure for training of management and specialists whose activities are related to the organization and implementation of measures on civil protection: Resolution of the Cabinet of 


\section{Науковий вісник : державне управління № 2(8) 2021}

Ministers of Ukraine of October 23, 2013 № 819].(2013, № 89). Official newsletter of Ukraine. P. 34 [in Ukrainian].

5. Postanova Kabinetu Ministriv Ukrainy Pro zapobihannia poshyrenniu na terytorii Ukraini hostroi respiratornoi khvoroby COVID-19, sprychynenoi koronovirusom SARS-CoV-2019 11 bereznia 2020 roku № 211[About the widening of the COVID-19 disease on the territory of Ukraine, caused by the coronavirus SARS-CoV-2019: Resolution of the Cabinet of Ministries of Ukraine of March 11 2020№ 211]. (2020, № 11).Official newsletter of Ukraine, P. 296 [in Ukrainian].

6. Postanova Kabinetu Ministriv Ukrainy Pro vstanovlennia karantynu ta zaprovadzhennia posylenukh protyepidemichnykh zakhodiv na terytorii zi znachnym poshyrenniam hostroi respiratornoi khvoroby COVID-19, sprychynenoi koronovirusom SARS-CoV-2019 22 lypnia 2020 roku № 641[About the imposition of quarantine and the prohibition of stronger antiepidemic visits to the territory of the significant expansion of the state respiratory ailment COVID-19, caused by the coronavirus SARS-CoV-2: Decree of the Cabinet of Ukraine of July 222020 № 641] (2020,№ 63). Official newsletter of Ukraine. P. 22 [in Ukrainian].

7. Postanova Kabinetu Ministriv Ukrainy Pro vstan ovlennia karantynu zmetoiu zapobihannia poshyrenniu na terytorii Ukrainy hostroi respiratornoi khvoroby COVID-19, sprychynenoi koronovirusom SARS-CoV-2 9 hrudnia 2020 roku№№1236 [About the introduction of quarantine with the aim of preventing an increase in the territory of Ukraine for the state of the respiratory ailment COVID-19, caused by the coronavirus SARS-CoV-2: Resolution of the Cabinet of Ministries of Ukraine of breast 92020 № 1236]. (2020, № 43) Newsletter of Ukraine. P. 118 [in Ukrainian].

8. Nakaz Ministersva osvity i nauky Ukrainy Pro zatverdzhennia Polozhennia pro dystantsiine navchannia 25 kvitnia 2013 roku № 466 [About the consolidated Provisions about distance science: order of the Ministry of Education and Science of Ukraine of April 25, 2013 № 466]. Official newsletter of Ukraine. 2013, № 36. P. 202 [in Ukrainian].

9. Shtykhno L. V. (2016). Dystantsiine havchannia iak perspektyvnyi napriam rozvytku suchasnoi ocvity [Distance learning yak promising direct development of modern education]. Molodiy vcheny. 6. $489-493$. Retrieved from http://nbuv.gov.ua/UJRN/molv_2016_6_123 [in Ukrainian].

10. Lishchynska L. B. (2017). Dystantsiine havchannia iak osvitnia tekhnolohiia: materialy mizhvuzivskoho vebinaru [Distance navchannya yak modern lighting technology: materials of the international webinar [Electronic resource]. Vinnytsia: VTEI KNTEU, 102 p. Retrieved from https://www.google.com/search?client=firefox-b-d\&q [in Ukrainian].

11. Romanovskyi O. H., Kvasnyk O. V., Moroz V. M., Pidbutska N. V., Reznik S. M., Cherkashyn A. I., Shapovalova V. V.(2019). Faktory rozvytku ta napriamy vdoskonalennia dystantsiinoi formy navchannia $\mathrm{v}$ systemi vyshchoi osvity Ukrainy[The factor of development and direct thorough understanding of the distance form in the system of food education in Ukraine].Information technology and information technology.6. t. 74. S. 20 - 42 [in Ukrainian].

12. Andros M. Ye. (2020). Pytannia orhanizatsii dystantsiinoho havchannia v nadzvychainykh osvitnikh umovakh [Nutrition for the organization of remote sensing in supervised intellectual minds]. Abstracts of the I All-Ukrainian Scientific and Practical Conference "Distance Education in Ukraine: 
Innovation, Normative Legal, Pedagogical Aspects" Kiev: NAU, zb. sciences. prats materials. Pp. 8 - 10 [in Ukrainian].

13. Chernenko K. V. (2020). Dystantsiine havchannia u vyshii shkoli v umovakh COVID-19 [Distance learning at other schools in the minds of COVID-19] Abstracts of the I All-Ukrainian Scientific and Practical Conference. Distance Education in Ukraine: Innovation, Normative Legal, Pedagogical AspectsKiev: NAU, zb.sciences.prats materials. Pp. 138-140). [in Ukrainian].

14. Gaiovych G. V., Romaniuk N. M. (2020). Vykorystannia system dystantsiinoho dostyru do informatsii v navchanni fakhivtsiv sfery tsyvilnoho zakhystu: praktychnyi dosvid [Victory of systems of remote access to information in new branches of the sphere of civil society: practical dosvid] Abstracts of the I All-Ukrainian Scientific and Practical Conference "Distance Education in Ukraine: Innovation, Normative Legal, Pedagogical Aspects"( pp. 26 -29). Kiev: NAU, zb.sciences.prats materials[in Ukrainian].

15. Lytvynovskyi Ye. Iu., Begun V. V., Geldash S. V., Gerasimenko A. V., Ivanov A. V. (2017). Teoretychni ta organizatsiino-metodychni zasady proektuvannia osvitnoi diialnosti navchalno-metodychnykh ustanov tsyvilnogo zakhystu: monografiia (zelektron.dod.) [Theoretical and organizationalmethodical ambush of the design of the educational activity of the initialmethodical installations of the civil society: monograph (from electronic dood.)] /.view.2, rerun.Lviv: Krugozir [in Ukrainian].

16. YurchenkoV. O. (2021).Vykorystannia innovatsiinykh form zdobuttia osvity ta metodiv navchannia dlia pidgotovky derzhavnykh sluzhbovtsiv I posadovykh osib mistsevogo somovriaduvannia.[Victory of innovative forms of education and methods of modernization for the preparation of state services and local specialties of self-assembly.Scientific bulletin: state management]. Naukovyi visnik: state management. No. 1 (7) [in Ukrainian].

17. Nakaz Ministersva vnutrishnikh sprav Ukrainy Pro deiaki pytannia orhganizatsii navchalnoho protsesu $\mathrm{z}$ funktsionalnoho navchannia 23 kvitnia 2019 roku № 302 [On some issues of the organization of the educational process of functional learning: the order of the Ministry of Internal Affairs of April 23, 2019 № 302].(2019, № 45).Official newsletter of Ukraine, p.136 [in Ukrainian].

18. Nakaz Ministersva osvity i nauky Ukrainy Pro zatverdzhennia Polozhennia pro dystantsiine navchannia 30 zhovtnia 2013 roku № 1518 [About the consolidation of Vimog to the new chief pledges and pledges of the educational education, scientific, educational and scientific installations, and the provision of educational services for the remote form of the introduction of preparation and punishment for the education of qualifications:order of the Ministry of Education and Science of Ukraine of October 30 2013, № 1518].(2013,№ 88).Official newsletter of Ukraine, p.156 [in Ukrainian].

19. Postanova Kabinetu Ministriv Ukrainy Pro zatverdzhennia Polozhennia pro systemu pidhotovku, spetsializatsii ta pidvyshchennia kvalifikatsii derzhavnykh sluzhbovtsiv i posadovykh osib mistsevoho samovriaduvannia 6 lutoho 2019 roku № 106 [On approval of the Regulations on the system of training, specialization and advanced training of civil servants and local government officials: Resolution of the Cabinet of Ministers of Ukraine of February 6, 2019 № 106]. (2019, № 19). Official newsletter of Ukraine, Pp. 43 - 52 [in Ukrainian]. 


\title{
Науковий вісник : державне управління № 2(8) 2021
}

\section{EXPERIENCE IN USING DISTANCE LEARNING FOR PROFESSIONAL DEVELOPMENT OF CIVIL SERVANTS}

\author{
Yurchenko Valery
}

\begin{abstract}
The article considers the procedure for organizing advanced training of management and specialists whose activities are related to the organization and implementation of measures for civil protection (hereinafter - functional training) of central executive bodies (hereinafter - CEB) and analyzes the organization of functional training with officials of management of civil management protection by distance learning. The article analyzes in detail the experience in using distance learning for advanced training in civil protection issues with this category of students, identifies the advantages and disadvantages of distance learning. The analysis of theoretical and practical aspects of the implementation of distance learning in the works of domestic scientists. The of competencies of officials of the management of the civil protection management bodies of the CEB, which are recommended to come through the main auditorium, competence, as the next step was to break the way of self-proclaimed education of the most professional technologists. The practical experience of the organization of advanced training of management and specialists whose activities are related to the organization and implementation of measures for civil protection of CEBs with the growth of distance learning in the introduction of strict quarantine (complete isolation) in due to the viral disease Covid-19. It is determined that the main efforts of research and teaching staff at the department are aimed at organizing interactive learning, development and implementation of components and methods of interactive technologies using computer support, quality development of methodological materials for theoretical and especially practical classes ONLINE. According to the results of the study established, a significant effectiveness of interactive learning in terms of learning material by students has been established. The authors of the article suggested an effective form of organization the educational process of functional learning using electronic resources and an algorithm for acquiring knowledge in the case of lockdown(complete isolation) due to the virus disease Covid-19 is proposed, the directions of further research on the topic are identified.
\end{abstract}

Key words: professional development, distance learning, civil protection, officials, functional training, public administration. 